\title{
The role of science, technology and innovation in increasing the share of renewable energy worldwide
}

\author{
Anna Tarasova ${ }^{1 *}$ \\ ${ }^{1}$ Department of Foreign Languages and Linguistics, Humanitarian Education Centre, Volga State \\ University of Technology, Lenin square, 3, Yoshkar-Ola, 424000 Russian Federation
}

\begin{abstract}
A number of countries in the emerging markets are becoming leaders in manufacturing solar photovoltaic products. Thus, global companies are urged to compete in all stages of the supply chain for producing most of the installed solar modules around the world. Meanwhile, production costs are at record lows. The decisions made in the emerging markets will affect the course for the solar and wind industry and their role towards de-carbonization of global energy systems in the near future. Renewable energy is set of miscellaneous natural resources, which preserves non-renewable sources for further use in other sectors of the economy, and saves green energy for future eras. The way a country employs its potential in renewables will safeguard the country's energy security and the stability of electricity prices. Renewable energy is eco-friendly, as its operation does not produce any waste, or discharge pollutants into the atmosphere or water bodies. Our paper discusses the latest achievements of various scientific areas and industries, as well as it lists specific recommendations for national sustainable actions plans. These recommendations might be useful for policy-makers, working in adopting the transformation of their country's energy systems.
\end{abstract}

\section{Introduction}

In 2015 one hundred ninety-three states, including those from the member states of the Commonwealth of Independent States (CIS), agreed on the 2030 Agenda for Sustainable Development, which includes 17 Sustainable Development Goals (SDGs). The Sustainable Development Goals and their associated targets are global in nature and universally applicable, while taking into account different national contexts. The goals aim at achieving universal access to affordable, reliable, sustainable and modern energy for all [1]. This means supporting and implementing the UNECE flagship project "Pathways to Sustainable Energy" that relies on sustainable energy described in three pillars:

1. energy security, an even supply of energy for economic growth;

\footnotetext{
*Corresponding author: tarasova_a@bk.ru
} 
2. energy for quality of life, providing energy available to all at all times;

3. energy and environment, limiting the impact of the energy system on climate, ecosystems and health.

International cooperation is a sine qua non for attracting investment in the development of renewable energy throughout the region and is one of the tools for expanding the use of renewable energy. One of the most important indicators of SDG is that by the year of 2030, strengthened international cooperation should facilitate access to research and technology in the field of clean energy, including renewable energy sources, energy efficiency and advanced clean technologies for the use of fossil fuels, and promoting investment in energy infrastructure and clean energy technologies [2,3]. Countries around the globe have already signed and ratified the Paris Climate Agreement, identified respective contributions and developed national action plans for their implementation. Most of the countries in the longterm plans for the development of the electric power industry provide for the large-scale development of renewable energy sources as one of the measures to limit greenhouse gas emissions. The expansion of the use of renewable energy sources became possible due to technical progress in this area, which made it possible to reduce significantly the cost of electricity production by wind and solar power plants of various types [4]. The electricity industry in many countries around the world is currently undergoing significant changes aimed at ensuring universal access to affordable, reliable, sustainable and modern energy for all. This goal can be achieved by the active integration of various traditional and renewable energy sources in a wide range of capacities from small-distributed generation facilities to large grid power plants, which entails the transformation of energy systems [5].

The ongoing technological changes are accompanied by the creation of an institutional framework that determines the regulatory, technological and economic rules for the reliable and efficient development and functioning of energy systems in new conditions. In other words, the process of creating an integral power management system, corresponding to the new structure of energy systems, is underway. Transformation of energy systems means an active process of creating political, market and regulatory conditions, as well as establishing practices for planning and operating energy systems that accelerate investment, innovation and the use of smart, efficient, reliable and environmentally friendly technologies $[6,7]$. Currently, the capacity of wind farms and solar photovoltaic power plants reaches hundreds and thousands of MW, and the energy sector is undergoing a fundamental shift towards a digitalized and decarbonized energy system. In this regard, an urgent task is to analyse the experience of large-scale development of renewable energy sources in a number of countries of the world, its impact, including negative, on traditional generation, on the electricity market and network infrastructure. Further step will be to develop specific recommendations on how to solve specific problems and obstacles in order to increase investment in renewable energy in each of the country involved, thus improving and optimizing cross-border regional energy cooperation [8].

\section{Global trends in renewable energy deployment}

Further development of cooperation among the countries in the electric power industry will be in the context of the transformation of energy systems, introduction of digital technologies, as well as expanded attention to environmental issues, energy efficiency, energy conservation and the development of renewable energy sources [9]. The implementation of the UN Sustainable Development Goals sets the following tasks for the Electric Power Councils in the countries-partners: 
-to assist the implementation of international agreements ratified in terms of environmental protection and mitigation of climate change; energy efficiency and energy saving;

-to hold measures to create a database on the best available technologies in the field of ecology and energy efficiency, including for manufacturers of power equipment, taking into account the possibilities of import substitution;

-to encourage dissemination of information on best practices, exchange of experience, including training in the field of renewable energy and energy efficiency.

Countries worldwide commence using the tidal energy potential to the full. Currently, it is cost effective to use tides with a height of at least 4 meters. The height of the tides is highly dependent on the configuration of the coast [10]. In the inland seas, for example in the Black and Baltic seas, the tides are low. The greatest tides occur in deep inland bays, including river estuaries, hence, the highest known tidal heights (up to $18 \mathrm{~m}$ ) are in the Bay of Fundy, Canada.

There are plots promising for the construction of tidal power stations in Russia, Great Britain, France, Norway, South Korea, China, Argentina, and the USA. Totally, the economically efficient potential for the use of tidal energy is currently estimated at 450 billion $\mathrm{kWh}$ per year; in the future, as tidal power plants improve, its value may significantly increase. Researchers around the world claim there are certain advantages of adopting tidal power plants [11]. These plants exploit renewable energy source, and do not generate waste. Moreover, they cause no flooding, occupying no land and minimally traumatizing fish and plankton that goes through the turbines.

Nevertheless, tidal power plants can be disadvantageous and highly scheduled, which means they are not stable in supplying electricity to the power system evenly, rather in several peaks during the day [12]. Hence, while implementing projects for the construction of specifically large tidal power stations with a capacity of several gigawatts, such a schedule can cause problems for the power system and require the construction of additional regulatory capacities, for example, in the form of a pumped storage power plant. Though the existing tidal power stations might have a certain effect on the local marine biocenosis, however, these changes do not lead to degradation of the biocenosis.

Since the Middle Ages people have used the tidal water farms; nevertheless, tidal power engineering has not received wide development and is still represented by several experimental power plants. The largest tidal power plant in the world is the French Rance with a capacity of $240 \mathrm{MW}$ that was launched in 1966 [13,14]. Other examples of such plants in operation are the Annapolis in Canada with a capacity of $20 \mathrm{MW}$, Jiangxia in China with a capacity of 3.2 MW and Uldolmok in South Korea. South Korea is showing great interest in tidal energy, where the Sihwa station with a capacity of $254 \mathrm{MW}$ is at the final stage of construction and the building of six more large tidal power stations is projected. Additionally, several more experimental small tidal power plants have been built in Norway and the UK.

One could ask the question as regarding to why the tidal energy has not been so widely used. The main reason is the lower economic attractiveness of such stations compared to traditional power plants. A classic tidal power station with high power requires the construction of an extended dam, the construction of a building in the sea area. Relatively small heads at high water flow rates necessitates the use of a large number of huge and expensive hydraulic units. Currently, a technology is being developed to reduce the cost of construction of tidal stations due to their construction from floating blocks and the use of orthogonal turbines [15].

Another example of renewable energy is solar energy, which has a colossal potential, far exceeding both current and future needs of humankind for electricity. If we cover only $0.7 \%$ of the globe with solar panels with a minimum efficiency of $10 \%$, their power generation will exceed the generation of all power plants in the world. Hydropower, wind energy, and 
bioenergy also carry the energy of the Sun, which is spent on evaporating water, heating air masses and the process of photosynthesis of plants. Due to the tilt of the earth's axis and the associated change of seasons, the largest average annual flow of solar energy per unit area falls on the equatorial regions - Africa, Central and South America, Australia, India, Southeast Asia. In Russia, the most promising for the development of solar energy is the south of the European part of the country, especially the Krasnodar and Stavropol Territories, Rostov, Volgograd and Astrakhan Regions, Dagestan and Kalmykia [16].

Solar energy uses an almost inexhaustible renewable energy source; there are no emissions of pollutants into the environment during the production of electricity. Moreover, solar panels can be installed in almost any convenient location. Nonetheless, among the disadvantages of solar energy, we should mention strong dependence of production on the time of day, season, and weather conditions [17]. With a relatively small share of solar and other unregulated energy in the power system, about 10\%), this feature does not cause significant problems. Additionally, a significant disadvantage is the high cost and, accordingly, the low economic efficiency of solar energy. Meanwhile, for large solar power stations, contamination of solar panels with dust, snow, and frost can become a problem.

Two methods of converting solar radiation energy into electricity that are being applied are photovoltaic and solar thermal. The photovoltaic principle is based on the generation of an electric current using solar cells, mainly silicon, collected in a panel. Panels of photovoltaic cells are easy to install, maintain and can be placed on any suitable area, such as roofs of houses, in this regard, it is solar energy based on photovoltaic cells that has become most widespread [18]. The solar thermal method is based on the concentration of sunlight using mirrors of various shapes. At the point where the sun's rays are concentrated, a heat carrier, such as water, is placed, which turns into steam and drives a turbine.

By the end of 2009, the total capacity of photovoltaic power plants alone in the world was about $23 \mathrm{GW}$, having increased 20 times in ten years. In 2010, at least $10 \mathrm{GW}$ of capacity was commissioned at photovoltaic power plants. The largest photovoltaic plant in the world - Sarnia in Canada with a capacity of $80 \mathrm{MW}$ was authorized [19]. About $70 \%$ of the capacity of solar power plants is concentrated in Europe, specifically in Germany, where the total capacity of solar power plants has exceeded $10 \mathrm{GW}$.

Solar energy is also developing in the USA and Spain. In the United States, back in 1991, the world's largest solar power plant with a capacity of $354 \mathrm{MW}$ was launched at full capacity, and in 2010, construction began on a solar thermal power plant in California with a capacity of 1000 GW. In Spain, in 2009-2010, six large solar thermal power plants with a total capacity of $450 \mathrm{MW}$ were accredited. However, there are still countries that do not recognize the potential of solar power stations and do not hasten to start including them in the energy systems [20].

The economic efficiency of solar thermal stations is highly dependent on their location, reaching a maximum in hot desert areas. Generally, the economic efficiency of solar energy in most cases is inferior to both traditional energy and other renewable energy sources. The payback of solar energy projects in developed countries is provided by various forms of government support and subsidies.

Apart from solar energy, global countries have commenced to use wind power plants. The United States are the leader in wind energy with $35 \mathrm{GW}$, followed by Germany with 26 GW and China with $25 \mathrm{GW}$.

Today, wind power stations provide about $2 \%$ of the world's electricity production. In a number of countries, these figures are significantly higher. Thus, in Denmark, wind farms provide about $20 \%$ of electricity generation, in Spain and Portugal - more than $10 \%$. Wind power is developing dynamically. The total wind farm capacity in the United States increased 3.9 times, in France - 5.6 times, in China - 19.8 times. Some researchers project further development of the industry [21]. For example, by 2030 the European Union plans to receive 
about $15 \%$ of electricity from wind farms, and some of its member states would desire to get even more. Ireland plans to achieve by this time the generation of wind power stations at the level of $40 \%$ of the total electricity generation in the country.

The world's economically efficient wind capacity is $72,000 \mathrm{GW}$, which is well above current needs. The use of wind power stations is considered economically efficient when the average annual wind speed at an altitude of $50 \mathrm{~m}$ is more than $6.4 \mathrm{~m} / \mathrm{s}$. Most often, such conditions can occur in coastal areas. Nevertheless, wind power is underdeveloped in some areas. The reason for that can be that wind energy in terms of its economic efficiency is inferior to classical energy due to the long payback periods. The production of wind farms depends on weather conditions and is therefore variable [22]. Wind power stations cannot guarantee the supply of a clearly defined amount of electricity in a specific period. This feature of wind power stations, as well as a number of other power stations, that operate based on renewable energy sources, should be fixed in the rules for the functioning of the electricity market.

Most countries have various government support measures for wind energy; such measures are declared at the legislative level, but pragmatically they do not work due to the lack of necessary by-laws.

\section{Technological drivers in renewable energy deployment}

This section analyses the energy systems in the countries around the world. In particular, it examines generation and grids and analyses the state of renewable energy in existing systems, such as installed capacity of power plants and electricity; dynamics of the total installed capacity of power stations in 2000-2020; finally, it scrutinizes the importance of renewable energy systems and their potential in the world [23].

Hydroelectric power plants capacity differs from country to country. Thus, they provide about $20 \%$ of Russian and world electricity generation. However, in other countries the share of hydropower can be dramatically higher. For example, in Canada, closest to Russia in terms of natural conditions, hydroelectric power plants produce $58 \%$ of electricity, in Brazil - $86 \%$, in Norway, which is known for its strict environmental legislation - 99\%. The Table 1 below lists the top ten countries in the use of hydropower in 2019 [24].

Table 1. The top ten countries in the use of hydropower, GW

\begin{tabular}{|l|c|c|}
\hline Country & HPP capacity, GW & HPP generation, billion $\mathrm{kWh}$ \\
\hline China & 196.79 & 585.2 \\
\hline Canada & 88.974 & 369.5 \\
\hline Brazil & 69.080 & 363.8 \\
\hline USA & 79.511 & 250.6 \\
\hline Russia & 44.426 & 176.0 \\
\hline Norway & 27.528 & 140.5 \\
\hline India & 33.600 & 115.6 \\
\hline Venezuela & 13.26 & 86.8 \\
\hline Japan & 27.229 & 69.2 \\
\hline Sweden & 16.209 & 65.5 \\
\hline
\end{tabular}

Currently, the global hydropower industry is experiencing a rebirth due to the active construction of hydropower stations in emerging countries such as China, Brazil, India, Pakistan, Iran and others. Only in China, it is drafted to double the capacity of hydroelectric power stations within the nearest ten years, this is in conditions when China is much ahead of other countries in terms of the installed capacity of renewable energy power stations [25]. 


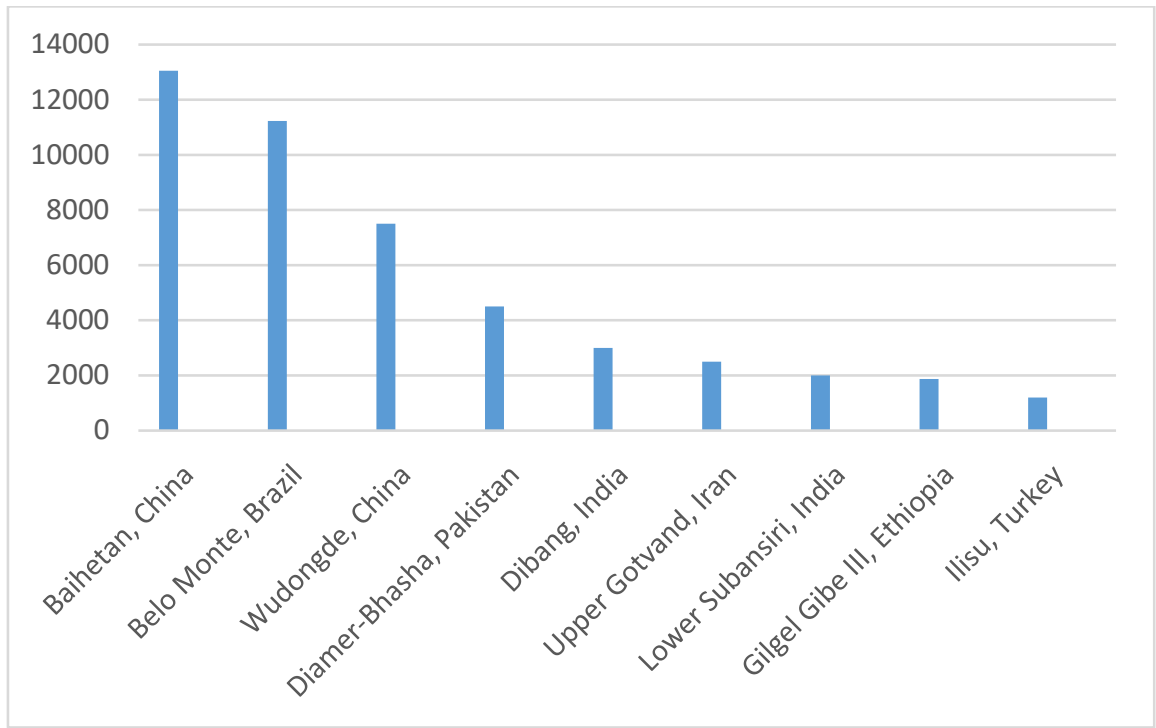

Fig. 1. Renewable energy power generated by world power stations (in bln kWh )

The energy sector is in transition and undergoing significant structural changes to ensure universal access to affordable, reliable, sustainable and modern energy for all. The key is transforming energy systems by integrating various conventional and renewable energy sources across a wide range of capacities. By creating policy, market and regulatory environments, countries can attract investment and accelerate innovation through smart grids, efficient, reliable and sustainable technologies. However, countries need to prepare to mitigate potential problems when trying to integrate renewable energy sources [26]. The future of the region's energy sector in accordance with various development scenarios looks different. Fossil fuel industries will be the hardest hit; however, they are essential for economic prosperity during the transition period.

It is designed that by 2050 , half of the world energy will continue to be powered by fossil fuels under any economically viable scenario. In all regions electricity generation, district heating and the transport sector will depend on fossil fuels. Thus, investments should be spread over a wider range of low-emission technologies to ensure a rapid transition to sustainable energy [27]. The results can be used to develop specific recommendations for national sustainable energy action plans. In the process of transformation of energy systems in a specific country, the following actions might be helpful:

- determination of key course and target vision for the development of the electric power industry, taking into account the long-term perspective (for the period up to 2050);

- creation of an institutional framework, and in general - an integrated management system that defines regulatory, technological and economic rules for the optimal development and functioning of the electric power complex in the context of the transformation of energy systems in the country and in the world;

- creation of a joint program for the development of a technological and economic basis for building a future efficient and sustainable integrated energy system to achieve SDG 7.

For the development of renewable energy in the project beneficiary countries, the authors recommend taking the following measures: 
- integrate solar and wind energy into energy systems;

- create national institutions for future energy planning;

- improve methods for unifying relevant, reliable and timely statistics;

- develop legislative measures to support the integration of variable renewable energy sources into power systems;

- use international experience to harmonize national and international energy standards;

- use modern technologies for efficient production of solar and wind energy;

- implement measures to reduce greenhouse gas emissions in the energy sector;

- improve the conditions for the modernization of energy systems using generation based on solar and wind energy;

- develop guidelines for potential investors in renewable energy facilities;

- train national personnel to integrate solar and wind generation into energy systems.

Renewable energy technologies extensively rely on digital technologies, hence, digitalization of the energy system that is growing and becoming more akin, smart, anticipated and sustainable should become a key future research area. Certain advances of automation, electric and shared mobility are today influencing the transport infrastructure and electric vehicles. Incurring to the traverse nature of mobility the future will surely see the way smart power grids pair and merge with electricity such as solar and wind power and transport systems on a wide scale [28]. Potentially greater energy efficiency and optimized energy consumption will become benefits of such emergence. However, much will depend on the way consumers accept, politicians adopt the right measures and the technological progress that will guide akin, automated, electric and shared mobility.

\section{Conclusions}

Currently, the electricity industry in many countries of the world is undergoing significant changes, the goal of which is to ensure universal access to affordable, reliable, sustainable and modern energy sources for all - SDG 7. This goal is achieved through the integration of various conventional and renewable energy sources in a wide range of capacities from small distributed generation facilities to large grid power stations, which entails the transformation of power systems.

No doubts that certain factors determining the rapid transformation of energy systems in the world will either speed up or slow down the shift. The desire to improve the reliability and efficiency of energy systems, as well as the desire to enhance the availability of energy using innovative technologies may be sufficient conditions for the countries to start thinking of opting for renewable energy. Another good reason is striving to ensure a high level of environmental and climatic safety, as well as reducing the cost of technologies for the production and consumption of electricity, thus encouraging the electrification of the economy by expanding of digitalization and automation of energy systems.

However, the use of renewable energy sources in combination with increased energy efficiency is the main measures to achieve the specified climate solution; a successful transition will require due consideration of three key aspects: technical, economic and institutional [29]. Improving coordination between transmission and distribution network operators is a priority. Moreover, new actors, such as aggregators, should become members in governance. Many countries around the world create positive political, market and regulatory conditions, as well as adopt practices for planning and operating energy systems 
that accelerate investment, innovation and the use of smart, efficient, reliable and environmentally friendly technologies. Comprehensive planning is key to ensure that different types of generation sources, transmission and distribution systems, demand management systems, energy storage devices, and other systems operate in a coordinated manner. Innovations can further improve and reduce costs of renewable energy technologies. This can include material science in solar photovoltaic cells, the integration of electric vehicles into the power grid and enabling digital technologies into the energy systems.

\section{References}

1. K. Prandecki, Energy and Environmental Engineering, 2(4), 83 (2014)

2. I. Sotnyk, I. Shvets, L. Momotiuk, Y. Chortok, Marketing and Management of Innovations, 4, 150-160 (2018)

3. W. Strielkowski, E. Lisin, E. Astachova, Entrepreneurship and Sustainability Issues, 4(4), 591-600 (2017)

4. I. Iddrisu, S.C. Bhattacharyya, Renewable and Sustainable Energy Reviews, 50, 513 (2015)

5. T. Tolstykh, L. Gamidullaeva, N. Shmeleva, Journal of Open Innovation: Technology, Market, and Complexity, 6(4), 95 (2020)

6. T. Beliaeva, M. Ferasso, S. Kraus, E.J. Damke, International Journal of Entrepreneurial Behavior \& Research, 26(2), 266 (2019)

7. D.-S. Oh, F. Phillips, S. Park, E. Lee, Technovation, 54, 1 (2016)

8. M.S.S. Danish, M.E.L. Elsayed, M. Ahmadi, T. Senjyu, H. Karimy, H. Zaheb, Energy Reports, 6(2), 40 (2020)

9. M. Sakah, F.A. Diawuo, R. Katzenbach, S. Gyamfi, Renewable and Sustainable Energy Reviews, 79, 544 (2017)

10. O, Zlyvko E. Lisin N. Rogalev G. Kurdiukova, International Economics Letters, 3(4), 124-138 (2014)

11. P. Woditsch, W. Koch, Solar Energy Materials and Solar Cells, 72(1-4), 11 (2002)

12. B.G. Gribov, K.V. Zinov'ev, Inorganic Materials, 39, 653(2003)

13. X. Zou, L. Ji, J. Ge, Nat Commun, 10, 5772 (2019).

14. N. Drouiche, P. Cuellar, F. Kerkar, S. Medjahed, T. Ouslimane, M.O. Hamou, Renewable and Sustainable Energy Reviews, 52, 393 (2015)

15. S. Mittal, H. Dai, S. Fujimori, T. Masui, Applied Energy, 166, 301 (2016)

16. Z.y. Zhao, S.-Y. Zhang, B. Hubbard, X. Yao, Renewable and Sustainable Energy Reviews, 21, 229 (2013)

17. J.W. Busby, S. Shidore, Energy Research \& Social Science, 23, 60 (2017)

18. X. Yu, C. Cecati, T. Dillon, M. G. Simões, IEEE Industrial Electronics Magazine, 5(3), 49 (2011)

19. J. Xu, T. Liu, Energy Policy, 142, 111538 (2020)

20. J. Wu, N.K.Tran, Sustainability, 10(9), 3067 (2018)

21. E. Lisin, W. Strielkowski, V. Chernova, A. Fomina, Energies, 11(12), 3284 (2018)

22. V. Stratigak, Water, 11(6), 1249 (2019)

23. M. van Staden, A. Marques, E. Villaseñor, Procedia, 57, 840 (2014)

24. I.R. Chávez Urbiola, J.A. Bernal Martínez, J. Hernández Borja, C.E. Pérez García, R. Ramírez Bon, Y.V. Vorobiev, Energy Procedia, 57, 24 (2014)

25. Y.A. Kaplan, Renewable and Sustainable Energy Reviews, 43, 562 (2015)

26. D. Y.C. Leung, Y.Yang, Renewable and Sustainable Energy Reviews, 16(1), 1031 (2012)

27. R. Saidur, N.A. Rahim, M.R. Islam, K.H. Solangi, Renewable and Sustainable Energy Reviews, 15(5), 2423 (2011) 
28. M. Shoaib, I. Siddiqui, S. Rehman, S. Khan, L.M. Alhems, Journal of Cleaner Production, 216, 346(2019)

29. A. Mostafaeipour, M. Khayyami, A. Sedaghat, K. Mohammadi, S. Shamshirband, M.A. Sehati, E. Gorakifard, International Journal of Hydrogen Energy, 41(15), 6200 (2016) 